\title{
Space in 150 years: \\ From fantasy through fiction to fact and function
}

\author{
David Southwood \\ Imperial College, London, SW7 2BZ
}

\begin{abstract}
In the last century and half, space has moved from the realm of fantasy to everyday reality. In parallel the way space has been regarded by the person in the street and the ideas of what access to space might be used for have evolved extraordinarily.
\end{abstract}

\section{Roots}

The roots of the story of space are considerably more than a century and a half ago. One place to start is around 400 years ago, when Galileo changed our view of space comprehensively. By turning a telescope on the cosmos he showed that not only did it have less than the perfection that Western scholars from Greece through to the Middle Ages had attributed to the cosmos, but also that the Earth was no more than one of the planets orbiting the Sun and the planets themselves could have moons orbiting them. Perhaps most importantly, he looked at the moon and saw it was riven by valleys, craters and hills, features not unlike our Earth. The idea that both space might contain worlds like our own and not only that but space might be accessible received impetus from that moment ${ }^{(1)}$. Not long after Galileo, the Englishman, John Wilkins, one of the founders of the Royal Society of London, suggested that the Moon would have its own population, the Selenites ${ }^{(2)}$. Writing before Newton's discovery of the nature of gravity, Wilkins was perhaps unsurprisingly overoptimistic about getting to the Moon. He proposed a vehicle with wings from high flying birds should do the trick, feeling that once the clouds had been surmounted, it would all be easy. Newton's discovery of the universal nature of gravity rather changed that.

\section{Fantasy}

Indeed space travel remained firmly rooted in fantasy until around 150 years ago.

Nonetheless, by the Victorian era large changes in attitude had come about because of the technical advances industrialised Western society had made. It was possible to speculate that not only travel through the air but also through space, the ether, could be achieved. Jules Verne is probably the best known of the dreamers of the Victorian era. His plots often contained a large element of the fantastic but his feeling for technology was still closer to the world he lived in. Nevertheless, one can find it serendipitous that the start of his novel ${ }^{(3)}$ Voyage to the Moon (or Earth to the Moon)is set in the aftermath of a war (the American Civil War) and the lunar voyage is in part to demonstrate the strength of US industry following that war. The voyage is American-led but contributions also come from a large variety of European nations. Only the British stand aloof; Verne reports this as due to jealousy of American capability. Some things are clearly wrong. The means of propulsion is a giant gun. Rockets still had a way to go to catch the imagination. Perhaps the most 
remarkable coincidence (or prescience?) is that after a debate between Texas and Florida over the launch site, Florida is chosen. That is not all. The spacecraft is called Columbiad, eerily pre-echoing the Apollo 11 craft, Columbia and return would be by splashdown in the Pacific. The size and shape of Columbiad even recall Columbia. Columbiad was launched in 1869. As he returned from the Moon, Neil Armstrong recalled the links and Verne's foresight in a broadcast from space on July $23^{\text {rd }} 1969^{(4)}$.

\section{Fiction}

At the end of the Victorian era, in 1895, the British writer, H.G. Wells brought space travel even closer to home. Although there remains fantasy in it, the "The War of the Worlds"(5) is better described as fiction. It is a seminal work of science fiction. Despite its title, one of the striking features of his book is that Wells descriptions of people and places firmly embed the story in the landscape of the outer suburbs of South West London and just beyond. The Martians arrive in the heathland of northern Surrey in projectiles, Wells also failing to anticipate the rocket. Part of the horror of the book is derived from the familiarity and commonplace nature of its milieu. Nonetheless, although giving a recognisable feeling of late $19^{\text {th }} \mathrm{C}$. London, Wells cannot resist thinking of the future. His Martians have flying machines which, in the decade before the Wright brothers flight, he describes with interest.

Wells was a biologist by training and his descriptions of the Martians allow him to bring out issues that are very relevant today. For me, I find his musings on the manner in which technology changes the relationship between sentient beings (I'm not sure the Martians can be described as human) and machines sensible. Here is what Wells protagonist remarks as he spies on the Martians

...the perfection of mechanical appliances must ultimately supersede limbs; the perfection of chemical devices, digestion; that such organs as hair, external nose, teeth and ears and chin were no longer essential parts of the human being, ...

\section{... The brain alone remained $a$}

cardinal necessity. Only another part of the body had a strong case for survival, and that was the hand, "teacher and agent of the brain."

Wells is a post-Darwinian. He is aware of evolution. Amusingly, his protagonist refers back to an article he recalls written by a "speculative writer of quasi-scientific repute" in the Pall Mall Budget of 1893. In that journal indeed one H.G. Wells had written an article entitled "The Man of the Year Million" where of course he had analysed how mankind might evolve with societal and technological advance. Finally of course, it is a prosaic biological phenomenon that defeats the Martians. They die from consuming terrestrial bacteria to which they have no immunity.

\section{Fact}

The age of rocketry followed hard on the heels of Wells. Robert Goddard, the American rocket pioneer, specifically acknowledged the reading of the Wells "War of the Worlds" as a motivation for his commitment to research to find a means for space exploration. Goddard 
could even precisely time his commitment. On a particular evening, October $19^{\text {th }} 1899$, at the age of 17 , he'd climbed a tree behind his family home to look at the night sky. He'd recently read Wells' book. When he climbed down from the tree he felt he had a purpose in life ${ }^{(6)}$.

In parallel in Tsarist Russia, Konstantin Tsiolkovsky was working on the theory of rocketry and he published his great work on the potential of rocketry for space exploration in the same year that the Wright brothers flew ${ }^{(7)}$. Not only did he derive his famous rocket equation but he advanced the idea of liquid fuels for propulsion and multistage rockets.

Goddard was a pioneer of liquid-fuelled systems and almost certainly had not known of Tsiolkovsky's theoretical work. Sadly, Goddard did not live to see even the dawn of the actual space age or indeed the use of rockets widely appreciated in his homeland.

Unappreciated as prophets often at home, his attempts to build multistage rockets to fly into space were made fun of as misguided in a New York Times editorial in 1920. In July 1969, just before the Apollo 11 astronauts landed on the Moon it saw fit to issue an apology. Sadly, Goddard had died a quarter of a century before. Thus although Goddard's experiments were eventually successful, rockets were not taken seriously in the USA until more or less after his death in 1945. Goddard himself became more and more reclusive and ideas of rocketry leading to spaceflight were taken less and less seriously. Indeed, one can discern a shadow of his difficulty even today. The Jet Propulsion Laboratory (JPL) in Pasadena California, now the centre of the US planetary exploration programme, began with research in rocketry in the Second World War. So tainted was the word "rocket" with the US military, who were providing the funding, that the word "jet" was used as a cover. I think it is true to say that JPL has never worked on what the rest of the world knows as jet engines.

It fell to workers in Germany and the Soviet Union to move rockets into a practical reality. Wernher Von Braun and his mentor, Hans Oberth, had always seen rockets as leading to space travel. However, it required military backing and a World War for the progress to proceed apace. Von Braun had begun as a teenager experimenting with rockets in a rocket club, "Verein für Raumschiffahrt", the society for space travel. By the early thirties the VfR was receiving German Army funding for its rocket work. [The end of the First World war had led to Germany being forbidden to undertake military research in many areas. However, rockets had not been included.] In a 1963 interview ${ }^{(8)}$ Von Braun credits Robert Goddard's ideas as helping the development of a liquid propelled rocket and certainly successful rocket flights were made in the early 30's. Eventually, the A4 rocket developed by Von Braun's team became the V2 German vengeance weapon towards the end of the Second World War.

Von Braun himself had an ambiguous relationship with the German Nazi party and with the SS. He certainly was a party member and it is clear he became an SS officer. At the same time, he became a pawn in the internal wrangling between the SS and the Army. At one point he was even arrested by the Gestapo for hindering the war effort. As the war drew to a close, Von Braun and his team were moved south from the Peenemunde site in the northeast to Bavaria in the south. In a complicated sequence of events they managed to avoid capture by the Russians and Von Braun and eventually many of the team were taken to the United States and based at the US Army Redstone Arsenal in Huntsville, Alabama. 
Despite evidently playing an important role in US missile development, Von Braun had not given up on his dream of spaceflight. By the 1950's Von Braun was appearing on television in the US advocating space exploration and describing plans for multistage vehicles to send astronauts to the Moon. However, it would need a stimulus from the outside for the US to turn a large effort towards such activities.

If Wells inspired Goddard and Oberth inspired Von Braun, Tsiolkovsky, a schoolteacher in Tsarist Russia, as already mentioned was the inspiration for Russian ambitions in space. By the time of the Second World War rocket research was established and seen as having potential military significance. Accordingly, it not too surprising that the Russians were first to put an artificial satellite into space. A team led by Sergei Korolev, launched a rocket putting a satellite, Sputnik 1, into Earth orbit on October $4^{\text {th }} 1957$. Known for many years only as the Chief Designer, Korolev's story is quite as strange as Von Braun's ${ }^{(9)}$. He too had started in a rocket society in the twenties and, as happened in Germany, the work was also picked up by the military. In a peculiar echo of the Von Braun's arrest by the Gestapo, Korolev too was arrested by the KGB. The consequence was far more serious for him. He spent six years in a labour camp. After the war, he emerged as a leader in the development of the Soviet missile programme.

\section{Function}

If Galileo's telescope changed how mankind thought about the universe, so did the advent of space travel change how we felt about our environment. Sputnik, technically part of a Soviet contribution to the International Geophysical Year, galvanised the world. In the US, President Eisenhower was caught in a public backlash for allowing the Russians to be first into space. There was widespread paranoiac reaction in the United States. The reaction ranged from wildly impractical hysteria over the Soviet capacity to put rockets on the Moon, to a more sane realisation that the Soviet Union had a real capacity to build and deploy intercontinental ballistic missile and to spy on the United States or indeed the whole world from the sky. Eisenhower, himself a military man, was taken by surprise by the public response but could take one immediate consolation from the beginning of the space age. $\mathrm{He}$ knew that his capability to spy on the Soviet Union using the ultra-high altitude U2 plane had a limited future. All such flights violated the air space of the USSR. In due course, the US would have to resort to the use of spy satellites and it was convenient that the Russians had been first to establish a precedent that a nation's sovereign air space did not extend endlessly upward.

For myself, a schoolboy in 1957, the advent of the space age was exciting but that the Russians had come first was an immense shock. Indeed, Sputnik made space seem very far away. Nevertheless, not really ever expecting a space career and certainly, not dreaming that by the end of that career I would have launched spacecraft from the same site as Sputnik was launched from launch in central Asia, I was immensely intrigued by what would happen next. When would there be astronauts, lunar landings and space stations? In fact, the first steps of space exploration did go pretty fast. The first astro/cosmonaut was the Russian, Yuri Gagarin, in 1961. An American, Neil Armstrong, was first to set foot on the Moon in 1969 and the first space stations appeared in the seventies. During that time, the general public 
followed the space race between the USA and USSR attentively. Nevertheless, no one can deny that the pace of establishing a human presence in space slowed dramatically after the goal of landing humans on the Moon had been achieved at the end of the sixties.

There is little doubt that the shear cost of a human exploration beyond the terrestrial system to Mars or elsewhere was responsible for radically changing the pace. An exultant NASA had followed up the Apollo success by outlining a programme to go on to Mars. President Nixon, the president who had greeted the Apollo astronauts as they returned from the Moon, probably had more pressing issues on his mind. He not only truncated the Apollo programme itself but set up a distraction, the very public goal of the link-up between East and West in orbit, the joint US-Soviet Apollo-Soyuz programme.

If human exploration has not gone as far as perhaps was anticipated 50 years ago, it is fair to say that the rate of robot exploration has disappointed less. Planetary science has been turned on its head as solar system body after solar system body has been approached and has turned out to surprise. Galileo upset the classical cosmos by showing four moons rotated about Jupiter. Who could have known that those objects when visited by spacecraft flying by would, each one, turn out to be so different. Ganymede has an internal magnetic field and its own magnetosphere, Europa has and internal ocean and Io turns out to be one of the most volcanic objects in the solar system. And Callisto? Well Callisto surprises just because it does not resemble any of its siblings. The wonder continues with just about every body visited yielding surprises. Moreover the physics of the Sun, of space itself, pervaded around the Sun by endlessly streaming plasma, and of the solar terrestrial interaction have been radically opened up.

Getting above the atmosphere of Earth revealed several new forms of astronomy. First was $\mathrm{X}$-ray astronomy which allowed us to see even black holes. From gamma rays to the infrared and microwaves, right across the electromagnetic spectrum, new phenomena were unveiled and our view of our universe was steadily reformulated. Everything from the Big Bang through the formation of galaxies, stars and planets as well as the birth and death of stars and the creation of the chemical elements has been explored.

\section{Function in everyday life}

It is easy to wax lyrical about what space technology has delivered to planetary and solar terrestrial research and astrophysics. Space has delivered so many things that were unanticipated but, in a sense, once one knew one could put instruments on a platform and point them to the stars unhindered by any intervening atmosphere, it was predictable that there should be much to exploit.

In a similar way, it was clear from the start of the space age that a space platform could be used to point instruments towards the Earth. One could use them for spying, for wider purposes such as to gather economically or strategically useful information, crop yields or water resources, for instance, or for improving services like weather forecasting. From there it is a small step or even climate change. 
Since Arthur C. Clarke's forward looking proposal for use of geostationary orbit for telecommunications, one could also foresee that there must be potential for enhancing telecommunications on a global level. However, a space application that I for one would never have guessed was the daily use of space for positioning and navigation. What remains generally not well known is that the first space navigation system was directly inspired by American scientists determining of Sputnik's orbit.

The story is documented by Helen Gavaghan ${ }^{(10)}$. George C. Weiffenbach ${ }^{(11)}$ and William H. Guier $^{(12)}$, colleagues at the Applied Physics Laboratory (APL) of Johns Hopkins University in Maryland were able to use equipment they had in their lab to study the telemetry signals received from the Soviet Sputnik satellite in the early days of October 1957. The Russians had made the signal very straightforward to identify, probably because they did not want it to be possible for anyone to claim that Sputnik was a hoax. It was not hard for Weiffenbach and Guier to detect Sputnik but after much work they were also able to demonstrate that the Doppler signals received from a single satellite pass provided all the information required for determining the satellite's orbit. They had won a race by many scientists across the globe to determine Sputnik's orbit!

However, that was only the beginning. Their boss, Frank McClure ${ }^{(13)}$, asked that they then inverted the problem to be able to determine accurately an observer's position on Earth if an orbit were known. They did not know, but their boss did, that if they could do it a significant Cold War problem could be solved, how to locate the new submarine-based nuclear system, Polaris.

As a result of the work by late 1959 APL was funded by the US Navy to develop a satellite navigation system. The outcome was the world's first successful satellite global navigation system, Transit. It was declared fully operational in 1964 and made available to civilian users in 1967. Inertial navigation systems were not reliable over more than days. If there were a satellite constellation (5 in the early stages) a submarine could surface, locate itself and submerge rapidly. The Polaris system thus became a serious deterrent.

Accuracy of the Transit system was on the scale of km and adequate for the navy's purpose. It took more than another decade before the probably better known group of Brad Parkinson, Roger L. Easton and Ivan A. Getting designed and persuaded the US Air Force to build the far more accurate atomic clock-based Global Positioning System used today. Ironically, the story that links the origin of the space age to the now almost ubiquitous use of space by ordinary people is the least well-known.

\section{Concluding Remarks}

In summary, the last 150 years have changed the way we humans think of space. It is probably true that the first thought of the person in the street is of human spaceflight and then of the enormous advances made in astronomy and space science. However, increasingly we are all are becoming regular beneficiaries and even users of space. Most people are aware of communications satellites and routinely we are used to things like immediate reportage on TV. Perhaps, more significant though is that through space technology we increasingly have 
the information to monitor our planet better and thus the potential to better manage it. Whether at the planetary level we have the collective political will and trust to turn this into the most efficient management of the Earth's environment remains a very open question. Meanwhile in day to day life we hardly think of space as we use our in-car GPS. GPS remains a military system and, for Europeans, under foreign control. In the past few years the European Union has become an increasingly big player in space. This is justifiably so, in light of the increasingly space-dependent future that is to come for us. This is despite the fact that most of us remain in ignorance of the vast potential of integrating positioning, remote sensing and communications space technology carry for that future.

Europeans in the street have become increasingly aware that Europe has a distinctive presence in space. In some countries it was the magnificent Mars Express mission a dozen years ago which rewrote Martian history (as much wetter) and also delivered the mainly British Beagle2 lander which failed to call home but which did land successfully. Everywhere in Europe there was an immense reaction to the successful landing in 2005 of the Huygens probe on the Saturnian moon, Titan, ten times further from the Sun than the Earth. Indubitably, the landing of Philae in the last year grabbed people's imagination worldwide. Whereas Huygens was launched by the USA and hitched a ride all the away to Saturn on the NASA mother ship, Cassini, the cometary orbiter, Rosetta, and its lander, Philae, were fully European. Moreover, the launch in 2004 was on a European Ariane 5 rocket from Europe's spaceport in Kourou, Guyane. The facts were duly noted in the USA. Soon, Mercury and Jupiter will see European probes as well as a close orbiter of the Sun; there are many more European achievements in space to come.

Let us end by recalling that Jules Verne foresaw the British standing aloof from space. For much of the space age, that was how it looked to many. Happily in recent years that position has very much changed. The Government has increasingly come around to seeing space not only as a form of pure science and as a means to inspire young people in learning STEM subjects, but also, and critically, as an economic driver as well. Government investment has been increasing and economic growth is resulting. Perhaps the alienation and distance from space that I felt as a British schoolboy in 1957 is finally disappearing.

\section{Notes}

(1) A very readable recent account of Galileo and the telescope's impact on the renaissance world is Allan Chapman: Stargazers: Copernicus, Galileo, the Telescope and the Church, Lion Hudson; Oxford, 2014

(2) https://en.wikipedia.org/wiki/John_Wilkins

(3) http://www.pagebypagebooks.com/Jules_Verne/Earth_to_the_Moon/index.html

(4) https://www.youtube.com/watch?v=-44Qk15w8Y4

(5) There are many editions of War of the Worlds by H. G. Wells, a recent publication is by Dover Thrift.

(6) http://genesismission.jpl.nasa.gov/people/biographies/goddard.pdf

(7) Tsiolkovsky, Konstantin E. (1903), "The Exploration of Cosmic Space by Means of Reaction Devices (Исследование мировых пространств реактивными приборами)", The Science Review (in Russian). 
(8) http://history.msfc.nasa.gov/vonbraun/recollect-childhood.html

(9) A straightforward history of Korolev is given by Deborah Cadbury Space Race: The Epic Battle Between America and the Soviet Union for Dominion of Space, Harper Collins (Fourth Estate) London, 2005.

(10) Helen Gavaghan, Something New Under the Sun: Satellites and the Beginning of the Space Age, Copernicus/Springer-Verlag, New York, 1998.

(11) http://www.jhuapl.edu/techdigest/TD/td2402/Williams.pdf

(12) http://www.jhuapl.edu/techdigest/TD/td3003/30_3-Memoriam-Guier.pdf

(13) http://www.jhuapl.edu/techdigest/td/td1901/pisacane.pdf 